\title{
The Inferences \& Nature of China's Transfer and Development of Technology from Higher Education Institutions to Industry
}

\author{
Chaudhry Talha Khan \\ University of Science and Technology of China, Hefei, China \\ Email: 1417552447@qq.com
}

How to cite this paper: Khan, C.T. (2018) The Inferences \& Nature of China's Transfer and Development of Technology from Higher Education Institutions to Industry. Open Journal of Social Sciences, 6, 12-34. https://doi.org/10.4236/jss.2018.69002

Received: July 30, 2018

Accepted: August 31, 2018

Published: September 3, 2018

Copyright $\odot 2018$ by author and Scientific Research Publishing Inc. This work is licensed under the Creative Commons Attribution International License (CC BY 4.0).

http://creativecommons.org/licenses/by/4.0/

\section{(c) (i) Open Access}

\begin{abstract}
In the nation's economic growth, the significance of technology and the growth of a viable advantage for companies cannot be over emphasized. It is obvious that in many developing and developed countries the higher educational institutions have been a main source of science and technology advancement. Therefore, the effective transfer of technology from higher educational institutions to companies or industry has been a vital concern on the behalf of governments and an appealing research topic on part of academics for more than two decades. This paper provides certain practical guidelines for government and companies concerned. The overall model presented in this paper address the main problem of the factors that affects higher education institutions performance in term of transfer and development of technology in China. A transfer and development of technology case study at Tsinghua University proposes that fruitful practice of transfer and development of technology already exist.
\end{abstract}

\section{Keywords}

Transfer and Development of Technology, Higher Education Institutions (HEIs), China, Science and Technology (S \& T), Gross Domestic Product (GDP). World Trade Organization (WTO)

\section{Introduction}

In the process of economic development and in providing the companies with deliberate advantages a substantial role has been played by the technology [1]. On the portion of academics and world-wide governments, there has been a significant attention in the transfer and development of technology from the Higher 
Education Institutes (HEIs) to the industries, in recent years. The universities in many counties like UK, USA, France, Germany and Japan in early 1980s have observed a transformation by augmenting their conventional goal of teaching, public assistance and research and becoming a dynamic contributor in the socioeconomic development of their regions [2] [3] [4]. This exercise in few universities can be found back in 1948, like an Industrial Liaison Program, was developed by the MIT in this year [5].

China has witnessed a phase of swift development regarding both technological and Gross Domestic Product (GDP) development in the past few years. In early 1990s, the Chinese's Research and Development (R \& D) institutes were generally isolated from the industry. Though, most of the innovative technologies are developed in the $\mathrm{R} \& \mathrm{D}$ institutes, including the HEIs. Thus, for the government of China, the transfer of technology from HEIs to the industry has continuously a deliberate problem. In China, the socioeconomic development is considered as a part of central government policy, so the government has devoted additional importance to the function of transfer and development of technology from the universities to the industry in the economic and social development. In the passage of the transfer and development of technology in China, there are also some sole characteristics and problems in addition to similar complications to those faced by the technologically advanced states in the previous and recent times [6] [7].

In the past thirty years, since executing the policy amendments and exposing the economy, China has sustained around 10 percent of the annual economic progress rate and turned into the globe's $2^{\text {nd }}$ biggest economy, in 2010. In 2012, the R \& D costs of China have been increased around 1.98 percent of the GDP approaching the 1.96 percent of European Union. In 2015, the R \& D costs have elevated to 2.1 percent and planned on attaining 2.5 percent by the end of 2020 . However, for the innovative system of China the industry has become a prime vehicle. Furthermore, the overseas financed firms regulate over 80 percent of high-tech innovative products that enter in China. So, to enhance its innovative dimension, the Science and Technology (S \& T) innovative system is considered as the China's key ingredient in its state's growth and development strategy. The transfer of technology is a main element of executing this innovative strategy because it's important for firms to attain $S \& \mathrm{~T}$ inventions and to boost their essential competitiveness to play a vital role in the nation's economy. Though, in the innovative system of China, the transfer of technology is considered as a feeble link, lacking constructive policy atmosphere, mechanisms and productive institutions. In China, these are considered as the major hurdles for firms refining their capacity to foster inventions with Chinese individualities fitting to their requirements So, an imperative strategic charge to develop a progressive and innovative country is to escalate the knowledge and transfer of technology flow to advance the nation's $S \&$ T transfer and development system and to establish an efficient operational structure for transfer and development of technology. 
This demands full commitment from the government, HEIs and the intermediaries [8] [9] [10] [11].

In the West, there has been a significant research on the transfer and development of technology from the universities to the industry, however, not much has been recognized regarding the nature and pattern of such events and activities in China [12] [13]. So, to pervade this gap, like a preliminary step, this research paper presents a frame for exploring the evolution and nature of the technology transfer and development. The second section covers the literature review, comprising a survey from West; different types, hurdles and government influence in the transfer of technology. In the third section, a model for the transfer and development of technology in China was developed comprising the influence of China's economic system, government, various constraints, motivation to transfer of technology and the financial administration. In the fourth section, the recent nature and pattern of transfer and development of technology from HEIs to industry in China were discussed. And in the fifth section, a transfer and development of technology case study at Tsinghua University was presented to exemplify a few optimum practices of China's transfer and development of technology, accompanied by the conclusion.

\section{Literature Review}

\subsection{The Transfer of Technology: A Survey from the West}

The technology transfer is a process by mean of which fundamental information, understanding and innovation shift from an institute, a university or a laboratory of government to the firms or individuals in the quasi private and private sectors [14].

\subsubsection{The Different Types of technology Transfer}

The technology transfer is of different types and forms, varying from a clear and pure transfer of knowledge by means of exchanging of the staff to the transfer of whole plant with the help for start-up and implementation [15] [16].

The various forms of transfer of technology among the research centers of university and private firms in the Western countries can be classified:

1) The spin-offs of the research centers of universities by means of research centers former employees and a central technology that was shifted from research centers [17] [18]. Such a transfer of technology is arisen in 1980s and typically occurred in high and advanced technology sectors [19]. A research presented that "MIT faculty and graduates have spun-off 3998 high and advanced technology firms, which have annual US \$232 billion of world-wide sales and employ over a 1.1 million people" [20].

2) Two other different perspectives have been discussed in another research. The first one regards the transfer of technology as a transaction of buyer and seller at a market price among the research center of a university and the firms. The second one is the relational perspective that considers transfer of technology 
to be a co-operative task happening inside an established system of informal and formal [21].

3) A fast growth has been observed in the last 30 years in the real-estate developments linked with the universities like innovation and research centers, Science and Technology Parks (STPs) with the main goal of assisting the transfer of technology among the universities and private sector [22] [23]. Several wide kinds of physical development have been identified in a research conducted in the Western Europe: a) The innovation and research centers are deliberating mainly for novel technology based firms. b) For both mature and new firms, the science parks will be developed. c) Technology parks encompasses a knowledge oriented firms, however their associations with the HEIs are more questionable [24].

4) The research article publications by the staff of university. This is the most often used kind of transfer of technology and with little effort it can reach the maximum number of individuals per individual reached. But, its unproductiveness is also well known, because the research articles are mainly written for the fellow researchers and scientists, so they can only be apprehended by them [20].

5) The personal contact perspective. In the transfer of technology this is believed as a critical part. The transfer of knowledge primarily occurs through associations among the contacts and inventors in business community [25].

\subsubsection{Hurdles to the Transfer of Technology}

The transfer of technology is a risky procedure as there is no assurance of maximum output from a technology development project. There are different hurdles in the transfer of technology that have been discussed in literature. Majority of the research concepts and outcomes generated in the university usually flop to orient with business policies of a firm or planning is inappropriate in connection to a product inauguration. There are propensities about risk prevention and uncertainty, deficiency of access to sales targets, and complications of reselling results or concepts that formerly had problems [26] [27].

Certain problems exist for small and intermediate sized enterprises, where the transfer of technology is often problem solution oriented rather tactical in nature, and lacks in pure or conceptual research [28]. In the product development course, the upper level management often present incomplete technology, fail to distinguish between the technology development and the product development and also underrate the effort and time needed to achieve the incorporation and transfer of a new and novel technology into an effort of product development [29] [30] [31].

From an academic view following various hurdles were found by the [15] in the transfer of technology: 1) lack of feasibility and practicality 2) attitude and stance of various professors 3) tendency towards perfectionism 4) lack of affection for profitability and deadlines 5) problems in communication 6) problems in confidentiality. 


\subsubsection{The Government Influence in the Transfer of Technology}

In the USA, UK, Japan, France and Germany a comparative research in the transfer of technology practices observed that the government of these countries are progressively highlighting and endeavoring to assist the infrastructure industry transfer of technology. Significant importance has been set on the transfer of technology to small and medium category firms. The government of US has taken perpetual steps to enhance transfer of technology within the universities of US for example the 1986 Federal transfer Act, the 12591 Executive order, the 1980s National Cooperative Research Act, guiding the federal agencies and governments to advance the technology transfer in the government laboratories [32] [33] [34] [35].

By and admiring the efforts of Japan and by following their footsteps, the governments of South Korea, Singapore and Taiwan also invested excessively in constructing a set-up for establishing high-tech goods that can compete in the global markets. In this effort, an important key to triumph is the development of STPs. The STPs in these countries brought the universities, government institutions, and small and large firms together in a cooperative effort to develop new advanced technological products influencing the global markets [36] [37].

\section{China's Transfer and Development of Technology: A Conceptual Background and Model}

A conceptual model in the transfer and development of technology for China is presented in Figure 1. According to this model, in China, there are a numeral factor that influences the transfer and development of technology. 1) The key

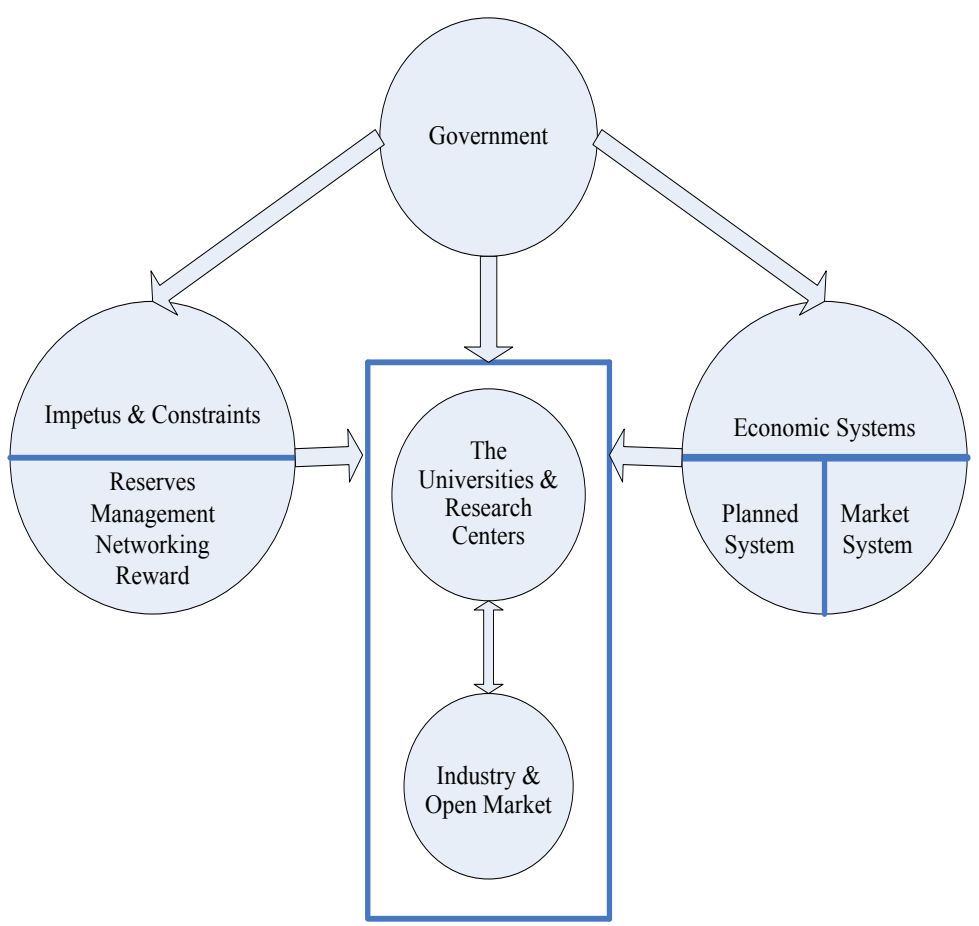

Figure 1. A model for China's transfer and development of technology. 
factor defined by the government is the economic system, based on the ideology and policy. 2) A direct influence of the government on the transfer and development of technology can be seen, as in the scenario of Western states. 3) The transfer and development of technology is correspondingly subject to a few impetus and constraints i.e. reserves, management, networking and reward [21] [26] [28].

\subsection{The Economic System and Transfer of Technology and Development}

An organized economic system was adopted by China from 1950s to 1980s which shaped the characteristics and nature of China's transfer and development of technology in that period.

1) The vertical administration governed the transfer and development of technology from the central government via regional governments and industry ministries to the universities and research institutions. The horizontal interaction or links among the universities and research institution in various systems barely existed. The main goal of the universities and research institutions were primarily to assist the firms and ministerial governments inside their industry. The transfer and development of technology were primarily held inside the industry [38] [39].

2) The ministerial governments assign tasks, $R \& D$ projects and funding to the universities and research institutions. However, the universities and research institutions have limited freedom and cannot choose or decide their research assignments or how to treat with results.

3) Technology and knowledge were not advertised and merchandise, and even selling in open market is also banned. According to the government's central strategies and plans all technological and innovative breakthroughs were owned by the government.

4) Research and innovation was isolated from the industry or open market. It is not possible for a researcher to appraise whether the results and outputs of research were appropriate and relevant to any manufacturing or production process. Similarly, the firm does not suggestions or views on what they demand in terms of their $\mathrm{R} \& \mathrm{D}$ constraints. The main errands of both research institutions and firms were to accomplish governments plans [38] [39] [40].

China has been shifted to a market oriented economic system from a planned system after the initiation of economic reforms in 1979. So, various reforms have been observed by the whole administrative system regarding the transfer and development of technology. Reforms were started by the government in early 1980s highlighting that the research should fulfill the requirements of national economic developments and R \& D projects should be developed by each research institution by means of methods of competition [41].

Stage 1: The reforms of S \& T management system were included in the stage 1 in 1986 which contained different areas like shifting the funding system, 
launching up technology market, integration of research and technology with production, boosting the capability of a firm to admit the new and novel technology etc. Among these actions, the main factor that has a massive impact on China's transfer and development of technology is the reform of funding system [41]. The State Council put up the succeeding main decisions in Feb. 1987: 1) The regional and central governments encouraged the universities and research institutions that are officially under their administration to interact and link with medium and large sized enterprises and be answerable for their own losses and profits. 2) The institutions that remained under the control of government, because of their compulsions to finish the research assignments contracted earlier the reform by the local or central governments, were also allowed to commence research assignments from other various sources and make revenues [42].

Stage 2. In 1995 this stage took place, when the 9th Year Plan of Domestic Economy \& Social Development was announced by the government. Importance of the reform of S \& T system were highlighted, emphasis was put on speeding and boosting up the reforms and creating the methods that will bound the scientific development, research, manufacturing and marketing firmly together. The universities and research institutions that primarily involved applied research and development were to be driven to link high-tech industry groups or to be transformed into high-tech firms. Medium and large enterprises were to be boosted to drive their own research \& technology centers [43].

Following modifications have arisen in the China's technology development and transfer system after these two stage reforms [12].

1) Vertical administrative and directorial links from the government to the university and research institutes have been weakened, however horizontal interactions or links among different research institutions and industries have been strengthened.

2) The universities and research institutions have acquired more independence from the government. They can know set their own research directions freely and can generate maximum profit.

3) The cross-sector research projects can be undertaken by the universities and research institutions without any constraints by their belonging industry.

4) The operational expenses and research project for the universities and research institutions were no longer be allocated by the government.

5) The scientific research and technology can freely be bought and sold in the open market. Many regulations and laws have been passed in China on marketing the results and findings of innovations or research, like Patent Law.

\subsection{Government and the Transfer \& Development of Technology}

From the above discussion, it is clear that the transfer of technology \& development is indirectly affected by the government policies. Yet, in the transfer of technology \& development the government also plays a main direct driving role, as in case of UK, USA, France, Japan, Germany, Korea, Singapore and Taiwan [37]. 
The Chinese government's science \& technology policy has primarily affected the behavior and direction of universities and higher research institutes transfer of technology in a substantial manner. The government's policy of $S \& \mathrm{~T}$ before 1980 was to reduce the vast technological gap among China and Western states as early as possible. So, additional importance was given to theoretical and basic research like physics, mathematics, chemistry and the fields related to heavy industry and national defense like, space technology, nuclear technology and metallurgical and chemical industries. In the early 1980s, the government's policy of $\mathrm{S} \& \mathrm{~T}$ was shifted towards the economic development and has focused the transfer of S \& T project results to productivity and user industry [33] [36] [37] [43].

China issued "the Law of Promoting Technology Transfer" in 1996 and started to award those individuals who have produced impressive contributions to transfer of technology. On average in China 70 percent of technological innovations are shifted to market every year according to the Ministry of S \& T's Department of Policy, Regulations \& System Reform. The ministries of foreign trade and economic cooperation and $\mathrm{S} \& \mathrm{~T}$ in 1998, funded an international symposium for transfer of technology regulations and laws, that attracted 100 specialists from USA, China and Australia [43].

The ministry of finance and education, and the State Development Planning Commission supported a programme called as "Project 211" in late 1995.The main goal of this programme is to make use to transfer of technology in promoting the economic and social development of China. This project helped in transferring the technology from the universities to local economic zones and encouraged exchange of IT between the universities and economic zones nationwide. Since the creation of People's Republic of China in 1949 this was the largest project related to universities and higher research education institutions which costs US $\$ 1.57$ billion [44] [45].

A new period of technology development and transfer was marked in 2011 when China entered in World Trade Organization (WTO). Yet, different researches showed that agreements of WTO don't encompass circumstances imposed on overseas investors or subsidies or incentives for investors. It is expected that China different other developing states will continue to enforce restrictive regulations or conditions on overseas investors [46].

Since 2013, policies have thus planned to drastically reform and broader the China's research and innovation institutions. In 2016, a broad national innovation plan, supported by full political assurance to reform, intended at spinning China into an S\&T center by 2050. Having sustained an average yearly GDP progress of around 9 percent among 2008 and 2013, the economy of China seems to have an elevated, categorized by leisurelier growth [47].

\subsection{Various Constraints of Transfer and Development of Technology}

According to a research every year over 20,000 big research projects were completed in China, but only 10 percent of them were applied to markets or industry 
effectively. This small rate of application is because of different hurdles that exit to the transfer of technology from research institutes to industry [48] [49].

\section{Hurdles from a Company Perspective}

The receivers of technology are the various companies and in common majority of them are not energetic in quest of technology because of the following causes:

1) Lack of strategy: For a company, the transfer of technology is a tactical measure and also a long-term plan. The managers in China normally give importance to the short-term performance. So, they are attracted towards the mature innovative technology that can give a short-term response. Different companies adopt a shortcut of importing the technology from the developing states in order to produce a fast short-term response [49].

2) Lack of capabilities in $R$ \& D: The transfer of technology is a two-way route and it also requires absorption and collaboration from the company side also, but in China many small and medium sized companies lack capabilities in R \& D and this directly affects the efficiency of the technology transfer [48].

3) Lack of finance: Many companies in China often face this problem. According to a research out of the successful transferred technology, the self-financed investment was around 56 percent, 23.8 percent was taken by national $R$ \& D projects, and 2.3 percent came from the risk investment [47] [50].

4) Hurdles from universities: Most of the universities in China mostly undergo from the budget constraint. By the transfer of technology, they can refill their budget and the staff salaries can be raised. So, many of the universities are energetically following transfer of technology activities. Various hurdles in academic perspective of technology transfer were identified by [15] and few of them can be seen in Chinese universities. a) The attitude of the universities and higher research institutions; b) The benefits distribution; c) The scholarly property rights protection.

\subsection{Motivation to Transfer of Technology}

Regardless of different factors in the transfer of technology, it is admitted that the function of universities and higher research institutions in the transfer of technology is increasing [47]. There are various mechanisms or motivations to promote transfer of technology.

\subsubsection{The Non-Financial and Recognition Incentive}

If a researcher in China achieves a hit that is well acknowledge by the higher organizations or media then this type of non-financial incentive is momentous. A well-known researcher would usually get imperceptible rewards like healthier welfare, promotion and extra opportunities for research funding and grants [51].

\subsubsection{The Financial Incentive}

Provided the un-balanced financial incentives among the source and receiver of transfer of technology, the trend of universities and higher research institutions spin-offs has arisen in transfer of technology. By means of this, the researchers, 
universities and higher research institutions where technology is renovated, can acquire reasonable financial incentives. As a result, thousands \& thousands of business have been created by the universities and few of them have turned into an icon of China's high-tech development [51].

\subsubsection{Networking}

"Soft" and "hard" are two kinds of networking. The soft networking specifies a close formal or informal relationship among the HEIs and industry. The society of China is a relation based, and therefore, as a form of distinct relationship among the universities and industry or among researchers, transfer of technology can habitually take place even if non-financial or financial incentives can't be as substantial as expected. The "hard" networking represents a transfer of technology network introduced by 7 universities, Beijing, Nanjing, Tsinghua, Fudan, Zhejiang, Xi'an Jiaoda and Shanghai Jiaoda, and permitted by the State Education Commission that is now renamed as the Ministry of Education (MOE). The main goal of this network is to create links among the universities and industry and is intended at offering transfer of technology services to the universities and firms around the country [52].

\subsection{Financial Administration}

By some 100 different competitive programs, around 30 various agencies directed central government $\mathrm{R} \& \mathrm{D}$ funding, resulting in disintegration of policy resolves, extravagant duplications and misaligning of inducements backing to extensive misconduct and corruption troubling Chinese science. The S \& T plans of the nation have been regrouped into five classes under a recent associated funding structure formulated by the Ministries of Finance (MOF) and $S \& T$ with the aims of using R \& D expenditures of government more effectively and of accomplishing the innovation rate chain, from basic and applied research to the commercialization, more efficiently. By 2017 these were to be directed by "professional research funding firms" as part of the struggle to lessen the part of state in the administration of national programs [53]. So, in 2013, MOST, circulated around US $\$ 3.44$ billion in public R \& D funding and so far, seven professional firms have been launched [47].

\section{An Overview of Transfer of Technology from HEIs to Industry in China}

\subsection{HEIs in China}

There were around 2914 HEIs, with more than 20 million students registered in mainland China, by the end of May 2017. Figure 2 presents an overview of the number of HEIs in China from 2006 to 2017 [54] [55], In mid 1990s, the "Project 211" for establishing 100 universities began, and has united over 700 higher educational institutions into around 300 universities and also, since 1999 there has been a rapid development of the private sector in mainland China has 


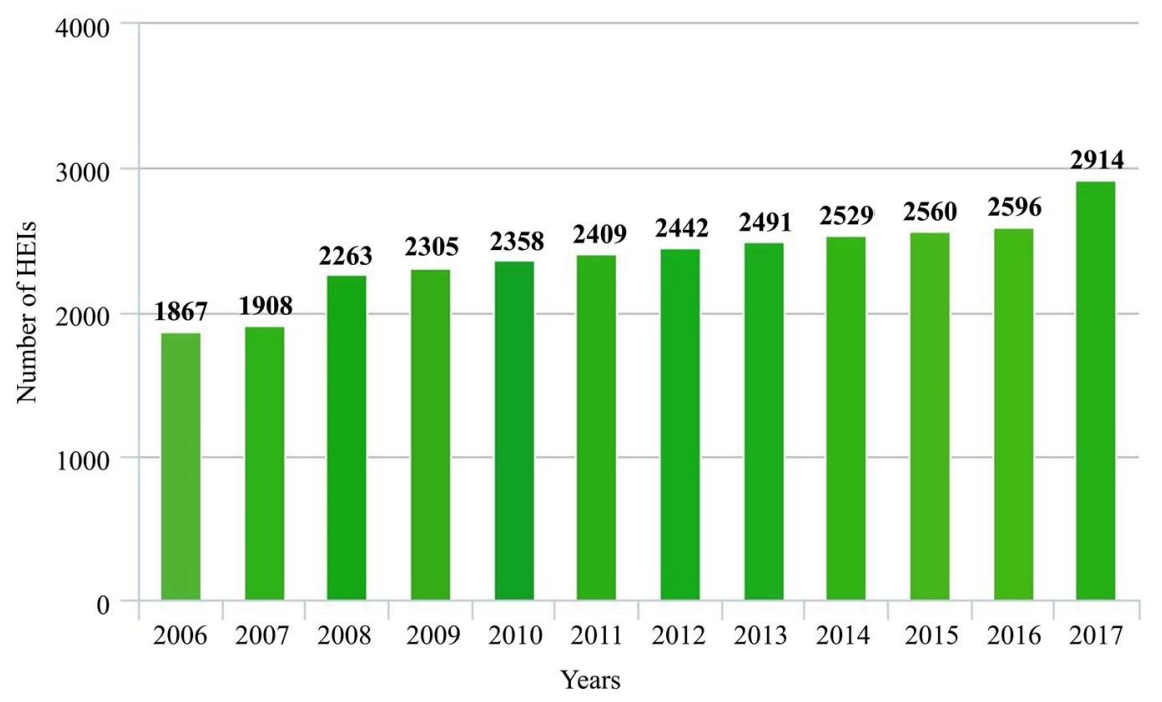

Figure 2. Number of HEIs in China from 2006-2017.

been observed [56], One research recorded that by the end of 2006, private universities accounted for about 6 percent, or around 1.3 million, of 20 million students registered in formal universities and higher educational institutions in China [57]. Table 1 presents the statistics of the HEIs in offering postgraduate programs in China, under the command of local authorities, Central Ministries \& Agencies and private sector. Table 2 presents the statistics of the Regular HEIs, under the command of local authorities, Central Ministries \& Agencies and private sector. Table 3 presents the statistics of the Adults and other non-government HEIs, under the command of local authorities, Central Ministries \& Agencies and private sector.

\section{The 13th Five Year Education Plan}

In January 2017, the Chinese State Council released the 13th five-year education plan, which set the principles, direction and targets for the growth of national education through the 13th Five Year plan period (2016-2020). According to this Plan, China by 2020 is likely to rank amongst the leading states in terms of growth in the innovation of education, human resources, overall education robustness and international influence, setting stable foundations for achieving the 2030 vision of a completely modernized system of education [58] [59].

\subsection{Transfer of Technology and the Varying Role of HEI}

According to a research, in past HEIs are conventionally been feeblest of all high research institutes in according to their impact to $S \& \mathrm{~T}$ research [60]. There have been a few long terms hitches in stabling the teaching levels and HEIs research, so this deduction was mainly centered on this fact. In 1980s, according to a research published by the State Education Commission, certain HEIs had comparatively robust potentials in S \& T research. So, it's the government faith that HEIs must put in extra to China's $S \& T$ research. Basically, two main tasks 
Table 1. HEIs in China offering Postgraduate programs in 2016.

\begin{tabular}{ccccc}
\hline Type & $\begin{array}{c}\text { Under Local } \\
\text { Authorities }\end{array}$ & $\begin{array}{c}\text { Under Central } \\
\text { Ministries \& Agencies }\end{array}$ & $\begin{array}{c}\text { Under Private } \\
\text { Sector }\end{array}$ & Total \\
\hline Research Institutions & 40 & 176 & 1 & 217 \\
Regular HEIs & 461 & 110 & 5 & 576 \\
\hline
\end{tabular}

Source: Compiled by the author from http://www.moe.gov.cn/ .

Table 2. Regular HEIs in 2016.

\begin{tabular}{ccccc}
\hline Type & $\begin{array}{c}\text { Under Local } \\
\text { Authorities }\end{array}$ & $\begin{array}{c}\text { Under Central } \\
\text { Ministries \& Agencies }\end{array}$ & $\begin{array}{c}\text { Under Private } \\
\text { Sector }\end{array}$ & Total \\
\hline $\begin{array}{c}\text { Higher vocational Colleges } \\
\text { HEIs offering degree }\end{array}$ & 1037 & 05 & 317 & 1359 \\
\hline
\end{tabular}

Source: Compiled by the author from http://www.moe.gov.cn/.

Table 3. Adults and non-government HEIs in 2016.

\begin{tabular}{ccccc}
\hline Type & $\begin{array}{c}\text { Under Local } \\
\text { Authorities }\end{array}$ & $\begin{array}{c}\text { Under Central } \\
\text { Ministries \& Agencies }\end{array}$ & $\begin{array}{c}\text { Under Private } \\
\text { Sector }\end{array}$ & Total \\
\hline $\begin{array}{c}\text { Adults institutes } \\
\text { Non-government }\end{array}$ & 270 & 13 & 1 & 217 \\
\hline
\end{tabular}

Source: Compiled by the author from http://www.moe.gov.cn/.

were assigned to HEIs: 1) to prepare highly qualified personnel with additional professional skills 2) To develop culture of S \& T. Since 1980s, three main points were covered in a modification idea that has been conducted at universities and colleges: 1) To promote and strengthen the horizontal link of 3 in 1 amalgamation of scientific research, education and production. 2) An appropriate reform in the system for $S$ \& $T$ funding administration. 3) Steady creation of a few open engineering R \& D centers and research labs [61].

In addition, State Planning Commission of China (presently named as $\mathrm{Na}$ tional Development Reform Commission (NDRC), initiated a plan to establish State Key Laboratories (SKLs) in 1984. In China, particularly for a basic research, the SKLs signify the finest research groups for a special topic. Its foundation is to allow the country's utmost talented scholars and scientists to conduct revolutionary research to further assist China's economic and technological development. There were 255 SKLs in 2015, with an overall budget of 4 billion RMB, primarily created in 132 different universities and 78 Chinese Academy of Sciences (CAS). Various other are within companies and ministries [62] [63]. Table 4 presents an overview of focus of SKLs in various fields.

\section{Transfer \& Development of Technology in HEIs: The Tsinghua University's Case}

With the slogan of "Self-Discipline and Social Commitment" and the essence of 
Table 4. Focus of SKLs in various fields.

\begin{tabular}{cc}
\hline Fields & Percentage \\
\hline Engineering & 16.8 \\
Biotechnology & 17.3 \\
Earth Sciences & 17.3 \\
IT & 12.5 \\
Medical Sciences & 12.2 \\
Material Sciences & 8.2 \\
Chemistry & 9.8 \\
Mathematics & 5.9 \\
\hline
\end{tabular}

Source: Compiled by the author from http://www.moe.gov.cn/.

"Actions Speak Louder than Words", Tsinghua University is a prestigious state university comprising disciplines of engineering, natural sciences, social sciences and management with major strengths and countrywide reputation in its field of engineering [64] [65]. Tsinghua University has its individual advantages, in terms of transfer of technology:

1) Highly Qualified Research Staff. Tsinghua University has around 5233 research and teaching staff, 46 of which are members of Chinese Academy of Sciences (CAS) and 34 are members of Chinese Academy of Engineering (CAE) [66]. Table 5 presents an overview of some important facts and figures regarding the Tsinghua University.

2) High quality Research Conditions. Tsinghua University resolutely recognized itself as a center for numerous key national research projects. Tsinghua University thoroughly focuses on attending the challenges confronted by both global and Chinese societies by creating creative and competitive solutions, boosting research efforts on global and strategic problems, and targeting for areas with substantial prospective importance. Moreover, Tsinghua energetically promotes the formation and expansion of platforms for international research associations. Recently in 2018, 154 national and ministerial labs and R \& D centers are being operated by Tsinghua University [64] [66]. Table 6 presents a detailed view of facts and figures of these labs and $\mathrm{R} \& \mathrm{D}$ centers.

3) A Hub for various significant R \& D Tasks and Projects. In 2017, among the 2nd batch of innovative National Key R \& D Projects, Tsinghua grabbed 29 different projects, and received 630 various research projects funded by the National Natural Science Foundation. Also, Tsinghua gained about 1400 extra research projects in the same year, funded by regional or central governments for various $\mathrm{S} \& \mathrm{~T}$ plans, and an overall contract amount is about 3.1 billion RMB. Moreover, the faculty in the departments of humanities received 735 projects in 2017, with an overall capital of 200 million RMB, including 3 key projects of Philosophy and Social Sciences Research and 13 national social sciences key projects backed by the MOE [66] [67]. 
Table 5. Facts and figures of Tsinghua University.

\begin{tabular}{cc}
\hline Facts & Figures \\
\hline Schools & 20 \\
Departments & 58 \\
Faculty & 3416 \\
Members of Chinese Academy of Sciences & 46 \\
Members of Chinese Academy of Engineering & 34 \\
Postdoctoral Researchers & 1817 \\
Registered students & 47,762 \\
Campus Area(hectare) & 450.38 \\
\hline
\end{tabular}

Source: Compiled by the author from http://www.tsinghua.edu.cn.

Table 6. Facts and figures of labs and R\&D centers of Tsinghua University.

\begin{tabular}{|c|c|c|}
\hline & Facts & Figures \\
\hline National Research Center (NRC) & Beijing NRC for Information S \& T & 1 \\
\hline $\begin{array}{l}\text { Large Research Infrastructure } \\
\text { (LRI) }\end{array}$ & $\begin{array}{l}\text { 1) National LRI for Protein Science of Beijing Base } \\
\text { 2) Earth System Numerical Simulation Facility }\end{array}$ & 2 \\
\hline $\begin{array}{l}\text { National Large Research Infrastructure (NLRI) for } \\
\text { Protein Science of Beijing Base }\end{array}$ & $\begin{array}{l}\text { 1) Beijing National Center for Electron Microscopy } \\
\text { 2) Beijing Electrons Spectroscopy Center }\end{array}$ & 2 \\
\hline State Key Laboratory (SKL) & $\begin{array}{l}\text { 1) SKL of Chemical Engineering } \\
\text { 2) SKL of Environmental Simulation and Pollution Control } \\
\text { 3) SKL of Low-Dimensional Quantum Physics } \\
\text { 4) SKL of Membrane Biology } \\
\text { 5) SKL of Precision Measuring Technology and Instruments } \\
\text { 6) SKL of Integrated Optoelectronics } \\
\text { 7) SKL of Microwave and Digital Communication } \\
\text { 8) SKL of Intelligent Technology and System } \\
\text { 9) SKL of Hydro-science and Engineering } \\
\text { 10) SKL of Tribology } \\
\text { 11) SKL of Automotive Safety and Energy } \\
\text { 12) SKL of Control and Simulation of Power System and Generation } \\
\text { Equipment } \\
\text { 13) SKL of New Ceramic and Fine Processing }\end{array}$ & 13 \\
\hline & $\begin{array}{l}\text { 1) NEL for Digital Television } \\
\text { 2) NEL for Electronic Commerce Technology } \\
\text { 3) NEL for Neuromodulation Technology } \\
\text { 4) NEL for Anti-Tumor Protein Therapeutics } \\
\text { 5) NEL for Next Generation Internet Backbone }\end{array}$ & \\
\hline National Engineering Laboratory (NEL) & $\begin{array}{l}\text { 6) NEL for Ultra High Voltage Engineering Technology } \\
\text { 7) NEL for Industrial Enzymes } \\
\text { 8) NEL for Green \& Safe construction technology in Urban Rail Transit } \\
\text { 9) NEL for flue gas multi pollutant control technology and equipment } \\
\text { 10) NEL for Dangerous Articles and Explosives Detection Technologies } \\
\text { 11) NEL for Big Data Software }\end{array}$ & 11 \\
\hline National Engineering Research Center (NERC) & $\begin{array}{l}\text { 1) NERC of Optical Memory } \\
\text { 2) NERC of Clean Coal Combustion } \\
\text { 3) NERC of Gas Turbine and IGCC Technology } \\
\text { 4) NERC for Beijing Biochip Technology } \\
\text { 5) National CIMS Engineering Research Center } \\
\text { 6) National Enterprise Information Software Engineering Research Center } \\
\text { 7) National Research Center of Traffic Management Engineering \& } \\
\text { Technology }\end{array}$ & 7 \\
\hline
\end{tabular}




\section{Continued}

National International S \& T Collaboration Base (International Joint Research Center)

National International S \& T Collaboration Base

Institute for Xi Jinping Thought on Socialism with Chinese Characteristics for a New Era

Tsinghua-Peking Uni. Joint Center for Life Sciences

Key Laboratory of Ministry of Education (MOE)

International Joint Research Laboratory (IJRL)

Engineering Research Center (ERC) of MOE

MOE-Microsoft Key Laboratory

Key Research Institute of Humanities and Social Sciences at Universities

Soft Science Research Base of MOE

Center for Education Strategy and Planning of MOE
1) New Energy \& Environment International Research Center (IRC) of MOST

2) Tsinghua University National Center of Novel Materials for International Research

3) International collaborative research center for functional materials

4) National Center for International Research of U.S.-China Clean Vehicle Technology

5) China-Latin America Joint Laboratory for Clean Energy and Climate Change

6) Sino-Russian International Joint Research Center for Aerospace Innovation Technology, Tsinghua University

1) State Key Laboratory (SKL) of Tribology

2) Institute for China-Russia Strategic Collaboration, Tsinghua University Institute for Xi Jinping Thought on Socialism with Chinese Characteristics for a New Era, Tsinghua University

Tsinghua-Peking University Joint Center for Life Sciences

1) Key Laboratory of Bioorganic Phosphorus Chemistry \& Chemical Biology

2) Key Laboratory of Industrial Biocatalysis

3) Key laboratory of Applied Mechanics

4) Key Laboratory of Earth System Numerical Simulation

5) Key Laboratory of Protein Sciences

6) Key Laboratory of Bioinformatics

7) Key Laboratory of Pervasive Computing

8) Key Laboratory of Particle and Radiation Imaging

9) Key Laboratory of Security for Information System

10) Key Laboratory of Urban-Rural Eco Planning and Green Building

11) Key Laboratory of Civil Engineering Safety and Durability

12) Key Laboratory of Solid Waste Management and Environment Safety

13) Key Laboratory of Advanced Materials Processing Technology

14) Key Laboratory of Thermal Science and Power Engineering

15) Key Laboratory of Advanced Reactor Engineering and Safety

16) Key Laboratory of Advanced Materials of Ministry of Education

17) Key Laboratory of Organic Optoelectronics \& Molecular Engineering

IJRL for Innovative Design and Manufacturing of Advanced Mechanical Systems

1) ERC of Energy Saving in Architecture

2) ERC of Intelligent Tech) and Equipment for Saving Energy and Increasing Benefit

3) ERC of Solid State Device and Integration Technologies

4) ERC Radiation Technologies and Radiation Imaging

5) ERC of Clean Energy Chemical Engineering

6) ERC of Nuclear Power Technology

7) ERC of Computer Network Technology

MOE-Microsoft Key Laboratory of Media and Networking, Tsinghua University

1) Research Center for Contemporary Management, Tsinghua University

2) Research Center for Technological Innovation, Tsinghua University

3) Research Center for College Moral Education, Tsinghua University

4) Research Center for Excavated Texts and Ancient Chinese Civilization

Research Center for Science and Education Policy, Tsinghua University

Center for Educational Strategy and Policy at Tsinghua University 


\section{Continued}

National Technical Support Center for Nuclear Emergency

MOE-China Mobile Joint Laboratory

Other scientific research bases of MOE

State Environmental Protection Key Laboratory

State Environmental Protection Engineering Center

Key Laboratory of Ministry of Culture

National Cultural Industry Research Center

Key Laboratory of S \& T of Press and Publication

State Sports Administration Key Research Base

State Work Safety Key Laboratory

Key Scientific Research Base of State Administration for Key Scientific Research Base of Space Information Technology of Tsinghua Cultural Heritage

Key Scientific Research Base of Space Information Technology of Tsinghua University

Beijing Innovation Center

Beijing Laboratory

Beijing Key Laboratory

Beijing Engineering Laboratory
National Technical Support Center for Nuclear Emergency Decision Making

Joint Lab for Internet of Vehicles MOE-China Mobile Communications Corporation

1) National Human Resources Institute for Service Outsourcing

2) Center for Online Education Research Ministry of Education

3) Yau Mathematical Sciences Center

1) Key Laboratory of Microorganism Application and Risk Control

2) Key Laboratory of Eco-Industry

3) Key Laboratory of Sources and Control of Air Pollution Complex

State Environmental Protection Eng. Center for Tech. Management \& Evaluation

Key Laboratory of Traditional Craft Techniques and Materials Research

National Cultural Industry Research Center, Tsinghua University

Key Laboratory of Digital Content Anti-Counterfeiting and Security Forensics

State Sports Administration Key Research Base for Sports and Social Sciences

State Administration of Work Safety: Research Laboratory of Fire Safety and Emergency Technology of National Key Reserve Facilities University

Key Laboratory of State Administration of Traditional Chinese Medicine for Chemical Research on Traditional Chinese Medicine

1) Beijing Advanced Innovation Center for Structural Biology

2) Technology Innovation Center on Chip of Excellence

Biomedical Detection Technology and Instrument Beijing Laboratory

1) Key Lab of Heat Transfer and Energy Conversion

2) Key Lab of Green Chemical Reaction Engineering and Technology

3) Key Lab of Membrane Materials and Engineering

4) Key Lab of Protein Therapeutics

5) Key Lab of Fine Ceramics

6) Key Lab of Precision and Ultra-Precision Manufacturing Equipment's and Control

7) Key Lab of CO2 Utilization and Reduction Technology

8) Key Lab of Networked Multimedia

9) Key Lab of City Integrated Emergency Response Science

10) Key Lab of Microanalysis and Instrumentation

11) Key Lab Bio-fabrication and Rapid Forming Technology

12) Key Lab of Nuclear Detection and Measurement

13) Key Lab Multi-Dimensional Multi-Scale Computational Photography

14) Key Lab Organic Emerging Contaminants Control

15) Key Lab Spatial Development for Capital Region

16) Key Lab Indoor Air Quality Evaluation and Control

17) Key Lab of Radioactive Waste Treatment

18) Key Lab of Industrial Big Data, Tsinghua University

19) Key Lab of Immunological Research on Chronic Diseases

Beijing Engineering Laboratory for E-Business Technologies 


\section{Continued}

Beijing Engineering Research Center

Introduction to Beijing International Science and Technology Collaboration Bases
1) Beijing Engineering Research Center of Biomass-to-Gas

2) Beijing Engineering Research Center of Multi-Modality Medical Imaging

3) Beijing Higher Institution Engineering Research Center of Visual Media

4) Beijing Engineering Research Center for Rail Passenger Service System

5) Beijing Engineering Research Center of wireless medical and health care

6) Beijing Engineering Research Center of Biofuels

7) Beijing Engineering Research Center for Ecological Restoration and Carbon Fixation of Saline-alkaline and Desert Land

8) Beijing Engineering Research Center of Composite Steel and Concrete Structures

1) Beijing International Collaboration Base on Sino-US Electric Automobile Technology

2) Beijing International Collaboration Base on High-tech Ceramic Materials and Tech)

3) Beijing International Collaboration Base on $\mathrm{CO} 2$ Utilization and Reduction Tech)

4) Beijing International Collaboration Base on Three-dimensional Printing

5) Beijing International Collaboration Base on Micro and Nano Device Technology

6) Beijing International Collaboration Base on Green Energy and Electric Power Safety

7) Beijing International Collaboration Base on Advanced Carbon Nanotube Macrostructures Materials

8) Beijing International Collaboration Base on Innovation and App) of Biofuels Tech

9) Beijing International Collaboration Base on Smart City Key Technology

10) Beijing International Collaboration Base on City Garbage Dry Fermentation Tech

11) Beijing International Collaboration Base on Efficient use of resources and control of harmful substances transfer

12) Beijing International Scientific and Technological Collaboration Base of Innovative Design and Manufacturing of Advanced Mechanical Systems

1) Center for Crisis Management Research

2) Anti-Corruption Research Base of Beijing

Institute for Urban Governance and Sustainable Development, Tsinghua University

Beijing Center for Organizational Learning and Urban Governance Innovation, Tsinghua University

Research Institute of Capital Internet Civilization

Laboratory of Parallel and Hybrid Mechanism and Control of Mechanical Industry

China Literary and Art Criticism Institute in Tsinghua University 


\begin{tabular}{l}
\hline 1) Center for Building Environment Test, Tsinghua University \\
2) Lab for Construction Materials, School of Civil Engineering, \\
Tsinghua University \\
3) Office of Building Safety Identification, Tsinghua University \\
4) Inspection Center for Structure Engineering of Tsinghua University \\
5) Institute for Hydrology and Water Resource, Department of Hydraulic \\
Engineering, Tsinghua University \\
6) Environmental Impact Assessment Division of Tsinghua University \\
7) Center for Environmental Quality Test, Tsinghua University \\
8) Industrial Evaluation Center for Energy Saving and Green Development, \\
Tsinghua University \\
9) Lab for Automotive Crash, SKL of Automotive Safety and Energy, \\
Tsinghua University \\
10) Office of Radiation Protection, Tsinghua University \\
11) Analysis Center, Tsinghua University
\end{tabular}

Source: Compiled by the authors from http://www.tsinghua.edu.cn/.

\section{Various Means of Transfer of Technology at Tsinghua University}

Since 1995, Tsinghua University has taken many measures to pursue transfer of technology: 1) Creation of the Tsinghua University-Industry Cooperation Committee of (UICCTU). 2) Transfer of technology by association with local governments. 3) Creation of high-tech firms in collaboration with enterprises. 4) Establishing an S \& T Collaboration Network of Chinese Universities (UNITECH). 5) Cooperation with enterprises [12].

\section{Conclusions}

In academia, the transfer and development of technology from Higher Educational Institutions (HEIs) to industry have been an extensively studied topic. Increasing the efficiency of transfer and development of technology has strategic inferences for both industries and nations. This paper presents an intangible model that addresses key elements of transfer and development of technology in China. The key factors comprise government initiatives \& policies, economic system, various constraints and motivation. Different researches on transfer and development of technology in China indicate that the HEIs of China have now become a main source of inventive and new technology.

The conceptual framework established in this paper concentrates on the essential problem of what issues affect the performance of Chinese's HEIs in forms of transfer and development of technology. On the basis of this framework, the subsequent fact can be formulated: the performance of HEIs in transfer and development of technology is the ramification of the nation's economic system that is regulated by the government's policy. A shift has been made by the China from the strategic to a market orientated economy, and hence the overall administrative formation and procedures of the research institutes have progressed via numerous fluctuations and therefore have the performance and behavior of the HEIs. The economic system of China is yet at an intermediate phase, with fusion of the government regulated and a market orientated economy. So, the 
Western models, practices and strategies frameworks regarding transfer and development of technology can be operated in the China with prudence.

It seems that various departments of the government have a significant part in managing and assisting transfer and development of technology in their individual systems, like the Ministry of $\mathrm{S} \& \mathrm{~T}$ and the Ministry of Education (MOE). It might be essential to have an allied committee among various sections to advance and execute strategies regarding the transfer and development of technology. The committee can often examine the suitable practices of the transfer and development of technology at different Chinese's HEIs and publicize these methods and practices among all the HEIs. A transfer and development of technology case study at Tsinghua University specifies that numerous fruitful practices and procedures even now exist and they can be encapsulated and propagated.

The overall discussions reflect that in China's S \& T system the HEIs have now acquired the central position and main source of innovative and new technology. The officials in China appreciate the complication they counter and prepare for phasing in fluctuations over many years. According to Chinese government, the economic development of China will be accelerated and the gaps among itself and developed states will be reduced. It means that the foreign states will have to face a progressively robust competitor.

\section{Conflicts of Interest}

The authors declare no conflicts of interest regarding the publication of this paper.

\section{References}

[1] Amankwah-Amoah, J., Osabutey, L.C.E. and Egbetokun, A. (2018) Contemporary Challenges and Opportunities of Doing Business in Africa: The Emerging Roles and Effects of Technologies. Technological Forecasting and Social Change, 131, 173-174. https://doi.org/10.1016/j.techfore.2018.01.003

[2] Main, S.A. (1997) Assessing and Managing the University Technology Business Incubator: An Integrative Framework. Journal of Business Venturing, 12, 251-285. https://doi.org/10.1016/S0883-9026(96)00063-8

[3] Chin, Y.W., and Lim, K.T. (2012) Networking and Knowledge Transfer in Malaysian SMEs through University-Industry Engagement and the State, Copenhagen. Journal of Asian Studies, 30, 96-116.

[4] Chau, V.S., Gilman, M., and Serbanica, C. (2018) Aligning University-Industry Interaction: The Role of Boundary Spanning in Intellectual Capital Transfer. Technological Forecasting and Social Change, 123, 199-209. https://doi.org/10.1016/j.techfore.2016.03.013

[5] Wright, R. (2008) How to Get the Most from University Relationships. MIT Sloan Management Review, 49, 75-80.

[6] Wang, B. and Christensen, T. (2015) The Open Public Value Account and Comprehensive Social Development: An Assessment of China and the United States. Administration \& Society, 49, 852-881. https://doi.org/10.1177/0095399715587522

[7] Xiang, D., Chen, J., Tripe, D. and Zhang, N. (2018) Family Firms, Sustainable Innovation and Financing Cost: Evidence from Chinese Hi-Tech Small and Medium-Sized 
Enterprises. Technological Forecasting and Social Change. https://doi.org/10.1016/j.techfore.2018.02.021

[8] Walcott, S. (2003) Chinese Science and Technology Industrial Parks. Routledge, London.

[9] Wu, W. (2010) Managing and Incentivizing Research Commercialization in Chinese Universities. The Journal of Technology Transfer, 35, 203-224. https://doi.org/10.1007/s10961-009-9116-4

[10] Schroeer, D. and Elena, M. (Eds.) (2017) Technology Transfer. Routledge, London.

[11] Hensengerth, O. (2018) South-South Technology Transfer: Who Benefits? A Case Study of the Chinese-Built Bui Dam in Ghana. Energy Policy, 114, 499-507. https://doi.org/10.1016/j.enpol.2017.12.039

[12] Liu, H. and Jiang, Y. (2001) Technology Transfer from Higher Education Institutions to Industry in China: Nature and Implications. Technovation, 21, 175-188. https://doi.org/10.1016/S0166-4972(00)00045-6

[13] Anderson, T.R., Daim, T.U. and Lavoie, F.F. (2007) Measuring the Efficiency of University Technology Transfer. Technovation, 27, 306-318. https://doi.org/10.1016/j.technovation.2006.10.003

[14] Parker, D.D. and Zilberman, D. (1993) University Technology Transfers: Impacts on Local and US Economies. Contemporary Economic Policy, 11, 87-99. https://doi.org/10.1111/j.1465-7287.1993.tb00382.x

[15] Corsten, H. (1987) Technology Transfer from Universities to Small and MediumSized Enterprises-An Empirical Survey from the Standpoint of Such Enterprises. Technovation, 6, 57-68. https://doi.org/10.1016/0166-4972(87)90039-3

[16] Arvanitis, S., Kubli, U. and Woerter, M. (2008) University-Industry Knowledge and Technology Transfer in Switzerland: What University Scientists Think about Co-Operation with Private Enterprises. Research Policy, 37, 1865-1883. https://doi.org/10.1016/j.respol.2008.07.005

[17] Rogers, E.M. and Steffensen, M. (1998) Spin-Offs. In: Dorf, R., Ed., Handbook of Technology Management, CRC Press, Boca Raton, 45-49.

[18] Meoli, M., Pierucci, E. and Vismara, S. (2017) The Effects of Public Policies in Fostering University Spinoffs in Italy. Economics of Innovation and New Technology, 27, 479-492. https://doi.org/10.1080/10438599.2017.1374048

[19] Rogers, E.M. (1986) The Role of the Research University in the Spinoff of High-Technology Companies. Technovation, 4, 169-181.

https://doi.org/10.1016/0166-4972(86)90010-6

[20] Rogers, E.M., et al. (1999) Technology Transfer from University-Based Research Centres: The University New Mexico Experience. Journal of Higher Education, 70, 687-705. https://www.jstor.org/stable/2649171

[21] Harmon, B., et al. (1997) Mapping the University Technology Transfer Process. Journal of Business Venturing, 12, 423-434. https://doi.org/10.1016/S0883-9026(96)00064-X

[22] Quintas, P., Wield, D. and Massey, D. (1992) Academic-Industry Links and Innovation: Questioning the Science Park Model. Technovation, 12, 161-175. https://doi.org/10.1016/0166-4972(92)90033-E

[23] Dong, L., et al. (2016) Towards Preventative Eco-Industrial Development: An Industrial and Urban Symbiosis Case in One Typical Industrial City in China. Journal of Cleaner Production, 114, 387-400. https://doi.org/10.1016/j.jclepro.2015.05.015 
[24] Park, J.M., Park, J.Y. and Park, H.S. (2016) A Review of the National Eco-Industrial Park Development Program in Korea: Progress and Achievements in the First Phase 2005-2010. Journal of Cleaner Production, 114, 33-44. https://doi.org/10.1016/j.jclepro.2015.08.115

[25] Cabrera, E.F. and Cabrera, A. (2005) Fostering Knowledge Sharing through People Management Practices. The International Journal of Human Resource Management, 16, 720-735. https://doi.org/10.1080/09585190500083020

[26] Lever, O.W. (1997) Selling and Marketing of R\&D. Research Technology Management, 40, 39-45. https://doi.org/10.1080/08956308.1997.11671141

[27] Urban, F. (2017) China's Rise: Challenging the North-South Technology Transfer Paradigm for Climate Change Mitigation and Low Carbon Energy. Energy Policy, 113, 320-330. https://doi.org/10.1016/j.enpol.2017.11.007

[28] Hee Jun, C. (2009) Technology Transfer Issues and a New Technology Transfer Model. Journal of Technology Studies, 35, 49-57. http://scholar.lib.vt.edu/ejournals/JOTS/v35/v35n1/pdf/choi.pdf

[29] Eldred, E.W. and McGrath, M.E. (1997) Commercializing New Technology I. Research Technology Management, 40, 41-47. https://doi.org/10.1080/08956308.1997.11671102

[30] Eldred, E.W. and McGrath, M.E. (1997b) Commercializing New Technology II. Research Technology Management, 40, 29-33. https://doi.org/10.1080/08956308.1997.11671114

[31] Kaushik, A., Kumar, S., Luthra, S. and Haleem, A. (2014) Technology Transfer: Enablers and Barriers-A Review. International Journal of Technology, Policy and Management, 14, 133-159. https://doi.org/10.1504/IJTPM.2014.060152

[32] Link, A.N. and Scott, J.T. (2006) U.S. University Research Parks. Journal of Productivity Analysis, 25, 43-55. https://doi.org/10.1007/s11123-006-7126-x

[33] Brown, H. (2008) Knowledge and Innovation: A Comparative Study of the USA, the UK, and Japan. Routledge, London.

[34] Holguin-Pando, N.C., Smyth, S.J. and Phillips, P.B. (2008) Technology Transfer in Transitional Economies: The Case of Mexico. International Journal of Technology, Policy and Management, 14, 111-132. https://doi.org/10.1504/IJTPM.2014.060144

[35] Algieri, B., Aquino, A. and Succurro, M. (2013) Technology Transfer Offices and Academic Spin-Off Creation: The Case of Italy. The Journal of Technology Transfer, 38, 382-400. https://doi.org/10.1007/s10961-011-9241-8

[36] Kim, H., Lee, Y.S. and Hwang, H.R. (2014) Regionalization of Planned S\&T Parks: The Case of Daedeok S \& T Park in Daejeon, South Korea. Environment and Planning C: Government and Policy, 32, 843-862. https://doi.org/10.1068/c1269r

[37] Link, A.N. and Yang, U.Y. (2018) On the Growth of Korean Technoparks. International Entrepreneurship and Management, 14, 405-410. https://doi.org/10.1007/s11365-017-0459-2

[38] Hu, A. (2015) Embracing China's "New Normal": Why the Economy Is Still on Track. Foreign Affairs, 94, 8-12.

[39] Green, F. and Stern, N. (2016) China's Changing Economy: Implications for Its Carbon Dioxide Emissions. Climate Policy, 17, 423-442. https://doi.org/10.1080/14693062.2016.1156515

[40] The State Science and Technology Commission of the People's Republic of China (1986) Guidelines to China's Science and Technology Policy-White Paper on Science and Technology No. 1. International Academic Publishers. 
[41] The State Science and Technology Commission of the People's Republic of China (1987) Guidelines to China's Science and Technology Policy-White Paper on Science and Technology No. 2. International Academic Publishers.

[42] The Development Research Centre of the State Council of PRC (1987) Almanac of China's Economy 1987. Almanac of China's Economic Publishing House, Beijing.

[43] The Development Research Centre of the State Council of PRC (1995) Almanac of China's Economy 1995. Almanac of China's Economic Publishing House, Beijing.

[44] Hu, Y., Liang, W. and Tang, Y. (2017) Exploring Factors Impacting on Research Efficiency in "211 Project" Universities. In: Hu, Y., Liang, W. and Tang, Y., Eds., Evaluating Research Efficiency of Chinese Universities, Springer, Berlin, 261-288. https://doi.org/10.1007/978-981-10-4030-6_6

[45] Zhou, C., Rasmussen, P., Chemi, T. and Luo, L. (2017) An Investigation of Creative Climate of University R\&D Centers and Policy Implications for Innovation in China. In: Jing, Y. and Osborne, S.P., Eds., Public Service Innovations in China, Palgrave Macmillan, London, 185-205. https://doi.org/10.1007/978-981-10-1762-9_9

[46] Qin, J.Y. (2004) WTO Regulation of Subsidies to State-Owned Enterprises (SOEs) - A Critical Appraisal of the China Accession Protocol. Journal of International Economic Law, 7, 863-919. https://doi.org/10.1093/jiel/7.4.863

[47] Cao, C. and Suttmeier, R.P. (2017) Challenges of S\&T System Reform in China. Science, 355, 1019-1021. https://doi.org/10.1126/science.aal2515

[48] Lewin, A.Y., Kenney, M. and Murmann, J.P. (2016) China’s Innovation Challenge: Overcoming the Middle-Income Trap. Cambridge University Press, Cambridge. https://doi.org/10.1017/CBO9781316422267

[49] Huang, C. (2017) Recent Development of the Intellectual Property Rights System in China and Challenges Ahead. Management and Organization Review, 13, 39-48. https://doi.org/10.1017/mor.2017.2

[50] Li, B.G., Zhou, J., Zhu, X.W. and Cui, H.J. (1997) On Problems Facing Science and Technology Risk Investment in China. Technoeconomics and Management Research, 49, 49-50.

[51] Allena, F., Qian, J. and Qian, M. (2005) Law, Finance, and Economic Growth in China. Journal of Financial Economics, 77, 57-116.

https://doi.org/10.1016/j.jfineco.2004.06.010

[52] Dorf, R.C. and Worthington, K.K.F. (1990) Technology Transfer from Universities and Research Laboratories. Technology Forecasting and Social Change, 37, 251-266. https://doi.org/10.1016/0040-1625(90)90026-R

[53] Liu, F.C., Simon, D.F., Sun, Y.T. and Caoc, C. (2011) China's Innovation Policies: Evolution, Institutional Structure, and Trajectory. Research Policy, 40, 917-931. https://doi.org/10.1016/j.respol.2011.05.005

[54] Haapanen, M. and Tervo, H. (2012) Migration of the Highly Educated: Evidence from Residence Spells of University Graduates. Journal of Regulatory Science, 52, 587-605. https://doi.org/10.1111/j.1467-9787.2011.00745.x

[55] Liu, Y., Shen, J., Xu, W. and Wang, G. (2017) From School to University to Work: Migration of Highly Educated Youths in China. The Annals of Regional Science, 59, 651-676. https://doi.org/10.1007/s00168-016-0753-x

[56] Wang, Q., (2017) A Differentiated Postsecondary Education System in Mainland China. In: Altbach, P.G., Reisberg, L. and de Wit, H., Eds., Responding to Massification, Springer, Berlin, 63-73. 
[57] Ministry of Education of China (MOE) (2009) Educational Statistics Yearbook of China 2009. People's Education Press, Beijing.

[58] Wu, H. (2018) Three Dimensions of China's “Outward-Oriented” Higher Education Internationalization. Higher Education, 1-16. https://doi.org/10.1007/s10734-018-0262-1

[59] Wang, B., Wu, C., Kang, L., Huang, L. and Pan, W. (2018) What Are the New Challenges, Goals, and Tasks of Occupational Health in China's Thirteenth Five-Year Plan (13th FYP) Period? Journal of Occupational Health, 60, 208-228. https://doi.org/10.1539/joh.2017-0275-RA

[60] Saich, T. (1989) China's Science Policy in the 80s. Manchester University Press, Manchester.

[61] The State Education Commission of the People's Republic of China (1987) Commentary by the State Education Commission on the Reform of the Scientific and Technological Work at the Institutions of Higher Learning.

[62] Jin, B. and Rousseau, R. (2004) Evaluation of Research Performance and Scientometric Indicators in China. In: Moed, H.F., Glänzel, W. and Schmoch, U., Eds., Handbook of Quantitative Science and Technology Research, Springer, Dordrecht, 497-514.

[63] Ahlgren, P., Yue, T., Rousseau, R. and Yang, L. (2017) The Role of the Chinese Key Labs in the International and National Scientific Arena Revisited. Research Evaluation, 26, 132-143. https://doi.org/10.1093/reseval/rvx011

[64] Wang, B. and Ma, J. (2007) Collaborative R\&D: Intellectual Property Rights between Tsinghua University and Multinational Companies. The Journal of Technology Transfer, 32, 457-474. https://doi.org/10.1007/s10961-006-9019-6

[65] Yang, R. and Welch, A. (2012) A World-Class University in China? The Case of Tsinghua. Higher Education, 63, 645-666.

https://doi.org/10.1007/s10734-011-9465-4

[66] Guo, F., Kang, N. and Shi, J. (2018) Preparation for the Scholar's Role: First-Year Doctoral Students in Tsinghua University. Asia Pacific Education Review, 19, 169-185. https://doi.org/10.1007/s12564-018-9529-6

[67] The National Bureau of Statistics of China (2017) China Statistical Yearbook 2017. China Statistical Publishing House, Beijing. 